\title{
PENGARUH LABEL HALAL PADA PERTUMBUHAN KOSMETIK DAN PANDANGAN WANITA MUSLIM NEGARA ISLAM DUNIA
}

\author{
Dinar Haidayatullah \\ Universitas Machung
}

\begin{abstract}
Even though the concept of halal is not a major concern among both Muslim and non-Muslim consumers living in an Islamic country, they are concern about the underlying advantages that come with halal products. Nowadays, Muslim consumers are faced with a broad selection of cosmetic products and services that offer multiple choices with different brands either locally or internationally. Halal cosmetic products are not only suitable for Muslim consumers, but also to non Muslims because of the nature of the products in terms of its ingredients and the methods used to produce these products. Thus this conceptual paper will explore the underlying determinants that are likely to influence non-Muslim and Muslim consumers' perceptions and attitudes towards halal cosmetic products in Islamic country. Recommendations for future research are also discussed.
\end{abstract}

Keywords :halal labelling, attitude, beliefs, cosmetics, moslem.

\section{PENDAHULUAN}

\section{Latar Belakang}

Dapat diketahui saat kini bahwa populasi Muslim di seluruh dunia meningkat dari waktu ke waktu. Diperkirakan bahwa populasi Muslim adalah 1,7 miliar dan akan tumbuh di tahun-tahun mendatang (Kettani, 2010). Esfahani dan Shahnazari (2013) menyatakan bahwa populasi Muslim mengambil 30 persen dari total populasi dan diperkirakan bahwa pada tahun 2025 jumlah penduduk Muslim akan meningkat hingga 35 persen. Karena ini, konsumsi produk halal meningkat dan begitu juga permintaan untuk produk halal.

Halal dari industri terkait telah menjadi pasar yang penting dan bisnis yang menguntungkan, belum lagi potensi yang besar dari investasi. industri halal meliputi makanan, non-makanan dan layanan daerah (Ahmad et al, 2011;. Hanzaee dan Ramezani, 2011). Di tiga kelompok yang disebutkan, non-makanan produk halal adalah pasar yang sangat baru untuk dieksplorasi (Abdullah Swidi et al, 2010;. Ahmad et al, 2011;. Ahlam Nuwairah et al, 2014.). Diantara produk non-pangan yang mementingkan label Halal adalah kosmetik, produk perawatan pribadi, produk kulit, nutraceuticals dan obat-obatan, dan peralatan makan. Hal ini karena produk ini digunakan dalam kehidupan sehari-hari dan memiliki kontak langsung dengan konsumsi manusia, sebagai makanan dan layanan. 


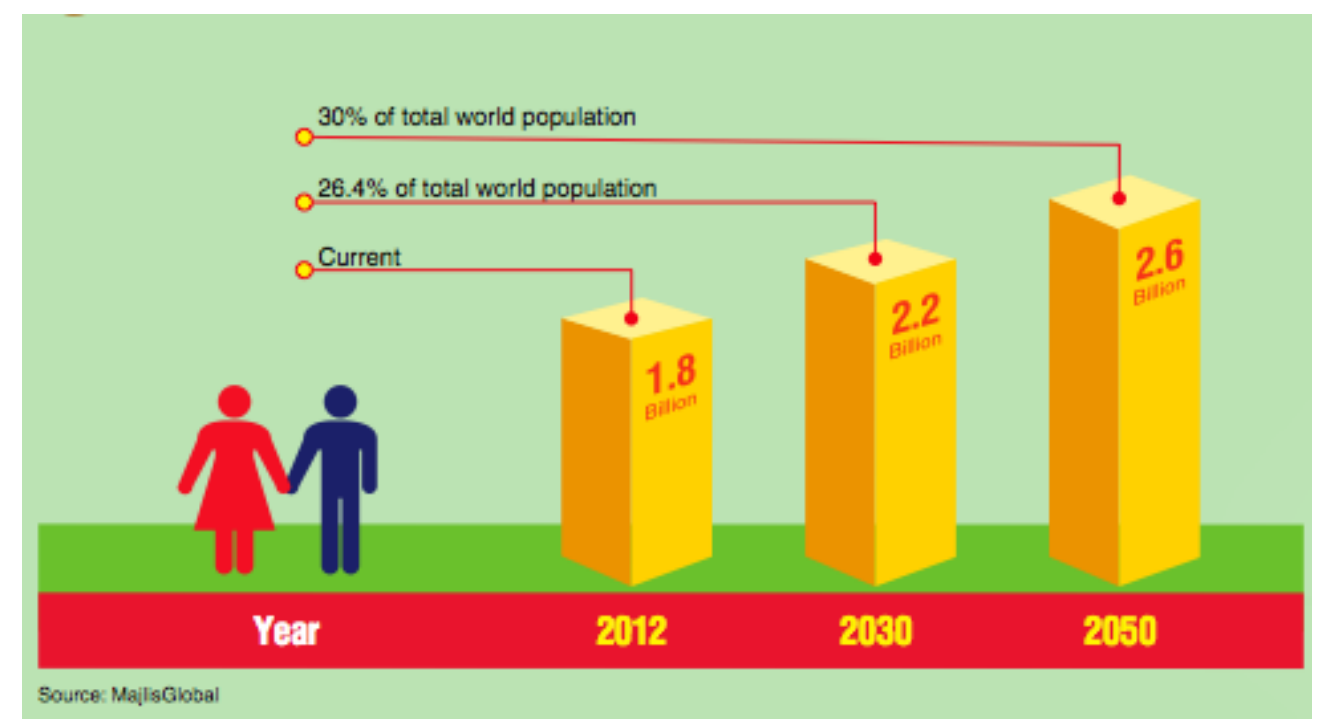

Gambar 1. Populasi Muslim Dunia

Di antara produk non-makanan saat ini mendapat perhatian pada kosmetik halal dan produk perawatan pribadi (Noor dan Eta, 2013). Semua produk seperti parfum, perlengkapan mandi, berbagai make up, dan berbagai perawatan kulit juga termasuk pada kelompok ini. Kosmetik halal dan industri perawatan pribadi adalah perhatian dunia sekarang, karena meningkatnya kesadaran di kalangan konsumen Muslim untuk mengkonsumsi produk halal dalam setiap bagian dari kehidupan mereka (Azreen Jihan dan Rosidah, 2014). Halal menjadi tren baru, maka produsen kosmetik dan produk perawatan pribadi mencari sertifikasi halal. Hal tersebut memberi mereka keuntungan pasar lain untuk menangkap pangsa pasar dan juga memberikan ketenangan pikiran kepada konsumen tentang apa yang mereka gunakan dan konsumsi adalah Halal. Kosmetik halal dan pasar perawatan pribadi memiliki begitu banyak potensi setelah industri makanan halal.

Sebuah penelitian yang dilakukan oleh World Sekretariat Forum Halal memperkirakan bahwa produk halal global adalah sebesar USD 2,3 triliun (tidak termasuk perbankan), dan 67 persen (Rp 1,4 triliun) pasar ini terdiri dari makanan dan minuman. USD 506.000.000.000 adalah dari obat-obatan dan USD 230 miliar terbuat dari kosmetik dan obat-obatan. (The Halal Journal (2010), juga dikutip oleh Zurina dan Wan Siti Khadijah (2012)).

Berdasarkan data dari Badan Pengawas Obat dan Makanan (BPOM)mengenai produk yang beredar di Indonesia tahun 2014 jumlah kosmetik yangberedar adalah 
sebanyak $67.1 \%$ dari total produk yang beredar sebanyak 49107jenis. Sebagai seorang pengguna produk kosmetik, setiap wanita pasti menginginkan barang yang aman, bermutu dan berkualitas. Tidak hanya itu, sebagai negara yang mayoritas penduduknya adalah beragama Islam, tidak cukup hanya produk kosmetik bermutu tapi juga ketersediaan kosmetik berlabel halal menjadi hal yang patut diperhatikan.

Hal ini karena hukum-hukum yang mempengaruhi perilaku konsumsi umat Islam telah diatur oleh filosofi dalam Alquran tentang apa yang diperbolehkan (halal) dan apa yang tidak boleh (haram) bagi pemeluknya (Mukhtar dan But,t 2012).Ada beberapa alasan untuk berfokus pada kata "halal" sebagai aspek branding. Pertama, halal mampu menjadi indikasi bahwa produk tersebut murni dan sehat. Kedua, membantu produsen kosmetik untuk menembus pasar baru dengan menambahkan nilai produk dalam lingkungan yang kompetitif. Terakhir, konsumen yang beragama Islam tidak dapat mengakses produk halal dimana saja seperti di pasar tetapi hanya di beberapa outlet (Baroozei dan Asgari, 2013 ).

Halal atau tidaknya suatu produkmerupakan suatu keamanan yang paling mendasar bagi umat Islam. Konsumen produk kosmetik yang beragama Islam cenderung memilih produk yang telah dinyatakan halal dibandingkan dengan produk yang belum dinyatakan halal oleh lembaga berwenang (Utami, 2013). Perlunya ketersediaan kosmetik halal juga karena masyarakat saat ini kebanyakan berpikiran secara sempit bahwa produk yang tidak halal hanyalah produk yang diproduksi dari babi atau alkohol.Padahal dalam ajaran Islam, suatu produk dikatakan tidak halal bukan hanyakarena substansi yang dikandungnya tetapi juga karena proses yang menyertainya(Iranita, 2013). 2013).

Tujuan pembahasan artikel menekankan pada apakah konsumen perempuan muslim pada beberapa negara muslim benar-benar memperhatikan ada atau tidaknya label halal pada produk kosmetik sebelum melakukan keputusan pembelian.

\section{TINJAUAN PUSTAKA}

\section{Halal}

Dalam Al-Qur'an, Allah berfirman, "Hai orang-orang yang beriman! Makan dari hal-hal yang baik yang Kami berikan untukmu, dan bersyukurlah kepada Tuhan, jika pada Dia kamu menyembah "(Al-Quran Al-Baqarah:. 172). Allah juga mengatakan dalam ayat lain, "Hai orang-orang! Makanlah dari apa yang ada di bumi, halal dan baik, dan tidak mengikuti jejak si jahat, karena ia adalah untukmu musuh diakui "(Al-Quran Al-Baqarah:. 168).. Disampaikan dari Bukhari, Muslim, Abu Daud, Ibnu Majah dan Darimi, "Apa yang 
Halal jelas. Dan apa yang Haram juga jelas. Dan di antara keduanya adalah daerah yang meragukan di mana banyak orang tidak tahu tentangnya. Jadi siapapun yang menjauhkan diri dari itu, ia telah dibebaskan dirinya (dari kesalahan). Dan orang-orang yang jatuh ke dalamnya, ia telah jatuh ke dalam keadaan Haram "(Halal Industry Development Corporation (HDC), 2014).

Halal pada dasarnya adalah sesuatu yang diperbolehkan berdasarkan syariah di aspek agama, iman dan spiritual sementara thoyyib baik atau sehat dalam hal kualitas, keamanan, higienis, bersih, bergizi, berkualitas, dan keaslian dalam aspek ilmiah (Che Man dan Mustafa 2010). Menurut Hunter (2012), thoyyiban juga mempengaruhi gaya manajemen, kebijakan sumber daya manusia, etika bisnis, baku pemilihan bahan dan metode manufaktur. Halal dalam Islam adalah Halaalan thoyyiban yang memberikan makna sastra, teknis dan praktis halal, higienis, bersih, murni, bergizi, berkualitas tinggi, dan sehat (Husain et al, 2012; Halal Industry Development Corporation (HDC), 2014).

Secara umum, Halal dalam perspektif industri adalah produk harus bebas dari alkohol dan babi oleh dan turunannya, namun lebih luas dan lebih rumit (Hashim dan Mat Hashim, 2013). Halal dalam kosmetik dan produk perawatan pribadi mencakup sampai ke bahan, masalah keamanan, dan proses produksi (Hashim dan Mat Hashim, 2013). Hal ini juga mencakup aspek-aspek lain seperti proses manufaktur, penyimpanan, pengemasan dan pengiriman yang harus sepatutnya memenuhi persyaratan Syariah (Hussin et al., 2013).

\section{Label Halal}

Labelisasi halal secara prinsip adalah label yang menginformasikan kepada pengguna produk yang berlabel tersebut, bahwa produknya benar-benar halal dan nutrisinutrisi yang dikandungnya tidak mengandung unsur-unsur yang diharamkan secara syariah sehingga, produk tersebut boleh dikonsumsi (Astogini et al. 2011). Dengan demikian produk-produk yang tidak mencantumkan label halal pada kemasannya belum mendapat persetujuan lembaga berwenang untuk diklasifikasikan kedalam daftar produk halal atau dianggap masih diragukan kehalalalnnya.

\section{Kosmetik}

Definisi kosmetik berdasarkan Peraturan Menteri Kesehatan RI No.1176/MenKes/Per/VIII/2010 adalah bahan atau sediaan yang dimaksudkan untuk digunakan pada bagian luar tubuh manusia (epidermis, rambut, kuku, bibir, dan organ 
genital bagian luar) atau gigi dan mukosa mulut terutama untuk membersihkan, mewangikan, mengubah penampilan dan/atau memperbaiki bau badan atau melindungi atau melindungi atau memelihara tubuh pada kondisi baik. Kosmetik juga merupakan suatu bahan yang digunakan pada tubuh manusia sebagai pembersih (cleansing), mempercantik (beautifying), penambah daya tarik (promoting attractiveness), atau pengubah penampilan (altering appearance) tanpa berakibat pada struktur atau fungsi tubuh.

\section{Kosmetik Halal}

Menurut Direktur Pelaksana LPPOM MUI, Lukmanul Hakim (2014), kosmetik halal merupakan kosmetik yang dalam proses pembuatannya memenuhi persyaratan halal. Hal ini berarti bahan yang digunakan haruslah berbahan halal dan suci serta diproduksi pada fasilitas produksi yang bebas dari kontaminasi bahan haram dan najis. Bahan baku yang diperbolehkan adalah yang berasal dari tanaman sepanjang dalam proses pembuatannya tidak mengunakan bahan aditif atau bahan penolong yang berbahan haram dan najis (www.halalmui.org diakses pada 15 Desember 2014). Secara umum bahan baku kosmetik yang dilarang adalah bahan dari bagian tubuh manusia, seperti plasenta dan keratin dari rambut manusia serta peralatan yang bahan-bahannya berasal dari bagian tubuh babi seperti kuas dari bulu babi.

\section{Perilaku Konsumen}

Perilaku konsumen didefinisikan sebagai tindakan yang langsung terlibat dalam mendapatkan, mengkonsumsi, dan menghabiskan produk dan jasa,termasuk proses keputusan yang mendahului dan setelah tindakan ini. Manusia pada umumnya sangat rasional dan memanfaatkan secara sistematis informasiyang tersedia. Orang mempertimbangkan implikasi dari tindakannya sebelum memutuskan untuk melibatkan diri atau tidak melibatkan diri didalam perilakutertentu (Setiadi 2008).

Dalam langkah-langkah keputusan konsumen ada beberapa faktoryang mempengaruhinya. Budaya adalah salah satu faktor yang sangatberpengaruh pada pola konsumsi atau perilaku konsumen di Indonesia. Trenlipstik pada masyrakat Indonesia saat ini adalah lipstik dengan tekstur matte danmencolok (http://female.kompas.com diakses 10 januari 2015). AmericanMarketing Association mendefinisikan perilaku konsumen sebagai interaksi dinamis antara afeksi \& kognisi, perilaku dan lingkungannya dimana manusia melakukan kegiatan pertukaran dalam hidup mereka. 


\section{Sikap}

Sikap adalah salah satu faktor yang sangat signifikan dalam mempengaruhi kesadaran dan persepsi produk atau peristiwa tertentu. Azmi et al. (2010) mengungkapkan bahwa sikap positif merupakan salah satu faktor yang menentukan keputusan untuk memilih kosmetik halal. Azreen Jihan dan Rosidah (2013) berpendapat sikap yang memiliki efek pada perempuan muslim muda perkotaan menuju kosmetik Halal berdasarkan Theory of Planned Behavior. Dimensi yang paling dibahas dalam sikap adalah kosmetik halal dari segi harga, logo Halal, label Halal dan masalah bahan. Teori yang sama juga dikemukakan oleh Noreen Noor dan Eta (2013) dengan variabel tambahan yaitu pengetahuan, kemurnian dan keamanan untuk niat pembelian kosmetik Halal.

\section{Keputusan Pembelian}

Dalam pengambilan keputusan semua aspek pengaruh dan kognisi dilibatkan dalam pengambilan keputusan konsumen termasuk pengetahuan, arti, kepercayaan yang diaktifkan dari ingatan serta proses perhatian dan pemahaman yang terlibat dalam penerjemahan informasi baru di lingkungan. Inti dari pengambilan keputusan konsumen adalah proses pengintegrasian yang mengkombinasikan pengetahuan untuk mengevaluasi dua atau lebih perilaku alternatif dan memilih salah satu di antaranya. Hasil dari proses pengintegrasian ini ialah suatu pilihan (choice) yang disajikan secara kognitif sebagai keinginan berperilaku.

\section{HASIL DAN PEMBAHASAN}

Pertumbuhan pasar kosmetik halal dicerminkan oleh pertumbuhan pengetahuan konsumen tentang bahan-bahan yang digunakan dan kesadaran produk, didorong oleh jaringan sosial. Industri kosmetik halal global diperkirakan USD13 miliar dengan tingkat pertumbuhan tahunan sebesar $12 \%$. Saat ini pasar kosmetik halal merupakan $11 \%$ dari total industri halal global. Pasar kosmetik dan perawatan pribadi halal muncul dilihat oleh para analis sebagai berikutnya sejalan untuk pertumbuhan setelah sektor makanan halal yang menguntungkan. 


\begin{tabular}{|l|l|}
\hline Clusters & $\begin{array}{l}\text { Potential Value for the Halal Market (USD) } \\
\text { (Based on 5\% of Global Halal Trade) }\end{array}$ \\
\hline Cosmetic/ Personal Care & 177 Billion \\
\hline Agriculture & 41.5 Billion \\
\hline Pharmaceutical & 30.3 Billion \\
\hline Islamic Finance & 25.0 Billion \\
\hline Logistic & 0.17 Billion \\
\hline Travel Inesustry & 0.13 Billion \\
\hline Total Value for Halal New Growth Clusters & 274.1 Billilon \\
\hline
\end{tabular}

\section{Gambar 2. Sektor Pertumbuhan Potensial}

Pendorong utama untuk permintaan besar ini dalam kosmetik halal dan produk kecantikan berasal dari demografi penduduk Muslim muda, sadar agama, dan dinamis. Dalam lingkup kosmetik halal, konsep mencakup aspek penting dari produksi seperti bahan halal dan penggunaan zat yang diizinkan yang harus diproduksi, disimpan, dikemas dan disampaikan sesuai dengan persyaratan syariat. Menariknya, kosmetik halal juga telah memperoleh momentum di antara konsumen yang modern yang sadar eco-etis dan bersedia membayar lebih untuk produk kosmetik organik, alami dan elegan untuk memenuhi gaya hidup modern mereka.

Pasar untuk kosmetik halal booming di Timur Tengah dan Asia. Di Timur Tengah, kosmetik halal yang mencatat pertumbuhan tahunan 12\% mencapai USD12 miliar total nilai penjualan kosmetik terkait. Pasar di Asia, khususnya Malaysia dan Indonesia serta Eropa, telah melihat lonjakan minat kosmetik halal. Di Malaysia, kosmetik halal berkontribusi $10 \%$ - $20 \%$ dari pasar kosmetik lokal. Namun, industri kosmetik global didominasi, dan untuk tingkat tertentu dimonopoli oleh perusahaan non-Muslim. Hal ini menimbulkan tantangan serius terhadap isu bahan halal di produk kosmetik yang diproduksi oleh perusahaan. Banyak produk kosmetik mengandung alkohol yang dianggap sebagai haram, dan komponen hewan bersumber dianggap najis oleh Islam.

Keprihatinan tentang bahan-bahan hewani seperti gelatin dan kolagen dalam produk kosmetik yang memicu bentuk permintaan baik konsumen Muslim dan nonMuslim. Label halal pada kosmetik dan produk kecantikan menarik bagi konsumen yang mencari integritas dan keaslian produk kosmetik dan perawatan pribadi mereka. Meskipun 
konsep kosmetik halal sangat baru ke dunia Muslim, ada permintaan terutama dari konsumen teliti yang menjadi lebih selektif dalam memilih produk perawatan pribadi, dan secara sadar memilih untuk menghabiskan uang pada kosmetik dan produk kecantikan yang cocok dengan persyaratan agama dan budaya mereka.

Kosmetik halal telah dikembangkan jauh melampaui hal yang baru. Dengan memanfaatkan pasar kosmetik halal yang sedang berkembang, sejumlah perusahaan kosmetik mulai mengembangkan ceruk pasar ini dengan memproduksi lini produk halal bersertifikat yang tidak mengandung bahan hewani, dan tidak diuji pada hewan untuk memenuhi permintaan konsumen yang hanya ingin lebih jaminan bahwa kosmetik yang mereka gunakan sehat dan ramah lingkungan. Sebuah tantangan untuk lebih mengembangkan ceruk sektor halal ini tentang bagaimana cara terbaik untuk mengintegrasikan kosmetik halal ke dalam kerangka industri kecantikan global. kolaborasi aktif seperti bahan organik, vegan, etika dan lingkungan dapat menjadi kunci untuk lebih memperkuat nilai produk kosmetik halal di pasar global.

\section{Implikasi Manajemen Pemasaran}

Berdasarkan pembahasan temuan terdahulu mengenai kepercayaan dan sikap konsumen Muslim wanita terhadap label Halal ketika membeli produk kosmetik yang mereka perhatikan selain hal-hal manusiawi lainnya, maka yang perlu dilakukan perusahaan dan merek utama kosmetik untuk mengoptimalkan penjualan adalah harus mengembangkan ceruk pasar kosmetik halal untuk wanita Muslim dengan melakukan mode sesuai dengan permintaan pasar yang menginginkan produk berkualitas dengan mutu sehat dan dapat diterima dalam religiusitas Muslim. Dan penggunaan tanda Halal harus jelas untuk paket produk mereka agar dapat meningkatkan niat pembelian Muslim dan konsumen Non-Muslim. Karena sebagian besar konsumen Muslim dan bahkan konsumen Non-Muslim memperhatikan label Halal dari produk untuk memilih produk yang diinginkan dibandingkan dengan memperhatikan untuk bahan produk.

\section{KESIMPULAN DAN SARAN}

Artikel ilmiah ini menghasilkan kesimpulan dari hasil beberapa karya tentang dampak label Halal dan pengaruhnya pada konsumen. Tanda-tanda Halal dalam artikel ini diteliti dari nama merek Halal, logo Halal, simbol Halal, pelabelan Halal dan sertifikasi Halal. Ditemukan bahwa tanda-tanda Halal memiliki pengaruh positif pada konsumen keputusan pembelian antara Muslim dan konsumen non-Muslim. Selain itu, label Halal 
pada produk adalah salah satu faktor paling penting yang mempengaruhi keputusan beli konsumen. Hal ini terlihat bahwa, konsumen Muslim terlebih kepada wanita Muslim yang memperhatikan sekali mengenai label halal daripada bahan produk itu sendiri. Karena kepercayaan mereka tinggi mengenai Halal, sehingga mereka percaya bahwa produk yang telah terdapat label Halal merupakan produk yang pasti aman, dan sangat layak untuk mereka konsumsi.

\section{DAFTAR PUSTAKA}

Abdullah Swidi, W.C., M.G. Hassan, A. Al-Hosam and A.W. Mohd Kassim. 2010. The mainstream cosmetics industry in Malaysia and the emergence, growth and prospects of halal cosmetics. The Third International Conference on International Studies (ICIS 2010), Sintok: Universiti Utara Malaysia.

Ahlam Nuwairah, A., A.R. Azmawani and A.R. Suhaimi. 2014. Accessing knowledge and re;ligiosity on consumer behavior towards halal food and cosmetics. International Journal of Social Science and Humanitu, 5(1): 10-14.

Ahmad, H., A. Fazullah, A.J. Borham, H. Hashim and M. Razak. 2011. Halal studies in universities: A way forward to manage halal business. Paper Presented at International Journal of Arts and Sciences Conference, Austria.

Astogini, Wahyudin, Wulandari. 2011. Aspek Religiusitas Dalam keputusan Pembelian Produk Halal. (Studi tentang labelisasi halal pada produk makanan \& minuman kemasan). JEBA, Vol.13, No.1, Maret 2011.Banyumas (ID) : Universitas Jendral Soedirman.

Azmi, A.A., A. Muslim and I. Zaidi. 2010. The perception to choose halal cosmetics products: An empirical study for Malaysian consumer. Paper Presented at 6th International Conference on Business, Management and Economics. Turkey: Yasar University.

Azreen Jihan, C.M.H. and M. Rosidah. 2013. Modeling the effects on the attitude of young adult urban muslim women towards halal cosmetics products: New insights for championing the halal economy. International Journal of Education and Research, 1(8): $1-8$.

Azreen Jihan, C.M.H. and M. Rosidah. 2014. Factors influencing attitude towards halal cosmetic among yound adult urban muslim women: A focus group analysis. Elsevier Procedia- Social and Behavioral Sciences, 130: 129-134.

Borzooei dan Asgari. 2013. The Halal Brand Personality and It's Effect on Purchase Intention. July 2013 VOL 5. NO 3. [jurnal]. Malaysia : Universiti Teknologi MARA.

Che Man, Y. and S. Mustafa .2010. Updates of halal products authentication. Presentation slides at world halal research summit 2010. Malaysia: Kuala Lumpur.

E-Halal Organization. 2010. Your Ultimate Guide To The World Of Halal Food. www.islamicpopulation.com

Esfahani, A.N. and A. Shahnazari. 2013. Designing halal and pure food model by emphasizing consumer behaviour management. Journal of Basic and Applied Scientific Research, 3(2): 574-578.

Halal Industry Development Corporation (HDC). 2014. Available from http://www.hdcglobal.com. 
Hanzaee, K.H. and M.R. Ramezani. 2011. Intention to halal products in the world markets. Interdisciplinary Journal of Research in Business, 1(5): 01-07.

Hashim, P. and D. Mat Hashim. 2013. A review of cosmetic and personal care products: Halal perspective and detection of ingredients. Pertanika Journals of Science and Technology, 21(2): 281-292.

Hunter, M., 2012. The emerging halal cosmetic and personal care market. Personal Care, $37-41$. Available from http://works.bepress.com/cgi/viewcontent.cgi?article=1021\&context=murray_hunt esiredir $=1 \&$ referer $=$ http $\% 3 \mathrm{~A} \% 2 \mathrm{~F} \% 2 \mathrm{Fscholar}$. google.com.my $\% 2 \mathrm{Fscholar} \% 3 \mathrm{Fstart} \% 3$ D30\%26q\%3DHalal\%2Bawareness\%26h1\%3Den\%26as_sdt\%3D0\%2C5\#search= \%22Halal\%20awareness\%22.

Husain, R., I. Abd Ghani, A. Mohammad and S. Mehad. 2012. Current practices among halal cosmetics manufacturer in Malaysia. Journal of Statistical Modelling and Analytic, 3(1): 46-51.

Hussin, S.R., H. Hashim, R.N. Yusof and N.N. Alias. 2013. Relationship between product factors, advertising, and purchase intention of halal cosmetic. Pertanika Journals of Social Sciences \& Humanities, 21(S): 85-100.

Iranita. 2013. Pengaruh Labelisasi Halal Produk Kemasan Terhadap Keputusan Pembelian Pada Mahasiswa Fakultas Ekonomi Universitas Maritim Raja Ali Haji. [skripsi] Available at : Riset.umrah.ac.id

Kettani, H. 2010. World muslim population. Proceedings of the 8th Hawaii. International Conference on Arts and Humanities. Honolulu Hawaii.

Mapping the GlobalMuslim Population" Pew Forum on Religion \& PublicLife, October 2009

Majlis Global, The NextBillion - The MarketOpportunity of The MuslimWorld. http://majlisglobal.com/wpcontent/blogs.dir/7/files/2011/07/Majlis_white_paper.pd $\underline{f}$

Mukhtar A dan Butt M. 2012. Intention to choose Halal products: the role of religiosity. [jurnal] Journal of Islamic Marketing Vol. 3 No. 2. 2012 pp. 108-120 q Emerald Group Publishing Limited 1759-0833 DOI10.1108/1759083121123519.

Noreen Noor, A.A. and W. Eta, 2013. Undesrtanding of halal cosmetics products: TPB model. 1st FPTP Potsgraduate Seminar 2013, 23 December 2013, UTHM.

Utami, W. 2013. Pengaruh Label Halal Terhadap Keputusan Membeli (Surveipada Pembeli Produk Kosmetik Wardah di Outlet Wardah Griya MuslimAn-Nisa Yogyakarta. [skripsi] Yogyakarta : Universitas Islam Indonesia

Setiadi, N. 2008. Perilaku Konsumen : Konsep \& Implikasi strategi dan Penelitian Pemasaran. Jakarta : Kencana Prenada Media Group.

The Pew Forum on Religion \& Public Life, The Future of the Global Muslim Population, Projections for 2010-2030.

Zurina, S. and W.M.N. Wan Siti Khadijah. 2012. Halal traceability framework for halal food production. World Applied Sciences Journal 17 (Towards the Traceability of Halal and Thoyyiban Application): 1-5. 